\title{
PENGEMBANGAN BAHAN AJAR CETAK DALAM BENTUK KOMIK UNTUK SISWA KELAS III SEKOLAH DASAR
}

\author{
Delora Jantung Amelia
}

\author{
Universitas Muhammadiyah Malang \\ e-mail: Delorajantung@umm.ac.id
}

\begin{abstract}
The purpose of the development research is to produce comic-shaped print teaching products that are used in third grade elementary school students. The existence of this development is to answer between ideal conditions and conditions in the field. The development model used in this study is the Dick, Carey and Carey model which has the following stages: 1) Identifying Learning Objectives, 2) Conduct Instructional Analysis, 3) Analyze Learner and Contexts 4) Write Performance Objective, 5) Develop Assessment Instrument, 6) Develop Instructional Strategy 7) Develop and Select Instruction, 8) Design and Conduct Formative Evaluation, 9) Revise Instrument. Presentation of data in this development research validation of content / material experts is needed as a form of evaluation of the content / material and presentation of products that have been developed. Based on the calculation of questionnaire data obtained from the validation of material experts shows the acquisition of $96 \%$. Language validation is needed as an evaluation of the language used in the product that has been developed, based on the calculation of questionnaire data obtained from linguist validation showing the acquisition of $92 \%$. Design validation is needed as an evaluation of the appearance of printed teaching materials. Based on the calculation of questionnaire data obtained from the validation, design experts show an acquisition of $86 \%$. Student learning outcomes reach $92 \%$
\end{abstract}

Keywords: teaching material, comic

\begin{abstract}
Abstrak: Tujuan pada penelitian pengembangan yaitu dapat mengahasilkan produk bahan ajar cetak berbentuk komik yang digunakan pada siswa kelas III SD. Adanya pengembangan ini yaitu untuk menjawab antara kondisi ideal dengan kondisi di lapangan. Model pengembangan yang digunakan pada penelitian ini yaitu model Dick, Carey and Carey yang memiliki tahapan-tahapan sebagai berikut: 1) Mengidentifikasi Tujuan Pembelajaran, 2) Conduct Instructional Analysis, 3) Analyze Learner and Contexts 4) Write Performance Objective, 5) Develop Assessment Instrument, 6) Develop Instructional Stategy 7) Develop and Selecting Instruction, 8) Design and Conduct Formative Evaluation, 9) Revise Instrument. Penyajian data pada penelitian pengembangan ini validasi ahli isi/materi diperlukan sebagai suatu bentuk evaluasi terhadap isi/materi serta penyajian produk yang telah dikembangkan. Berdasarkan perhitungan data angket yang diperoleh dari validasi ahli materi menunjukkan perolehan sebesar $96 \%$. Validasi bahasa diperlukan sebagai evaluasi terhadap bahasa yang digunakan dalam produk yang sudah dikembangkan, berdasarkan perhitungan data angket yang diperoleh dari validasi ahli bahasa menunjukkan perolehan sebesar 92\%. Validasi desain diperlukan sebagai evaluasi terhadap tampilan bahan ajar cetak Berdasarkan perhitungan data angket yang diperoleh dari validasi ahli desain menunjukkan perolehan sebesar $86 \%$. Hasil belajar siswa mencapai $92 \%$
\end{abstract}

Kata Kunci: Bahan Ajar, Komik

\section{PENDAHULUAN}

Pelajaran Bahasa Indonesia merupakan salah satu aspek penting yang perlu diajarkan kepada siswa di tingkat Sekolah Dasar. Bahasa merupakan hal yang penting pada pembelajaran karena bahasa merupakan alat penyampai suatu maksud dan tujuan. Bahasa Indonesia merupakan suatu alat pemersatu dari sabang sampai marauke, yang mana pembelajaran Bahasa Indonesia dikemas dalam bentuk mata pelajaran yang diajarkan di setiap jenjang pendidikan, salah satunya adalah Sekolah Dasar (SD). Pada mata pelajaran Bahasa Indonesia di SD belajar bahasa belajar bahasa sebagai 
belajar berkomunikasi dan belajar sastra untuk menghargai manusia serta nilainilai kemanusiaannya. Bahasa Indonesia sendiri memiliki ruang lingkup yang mencakup empat aspek keterampilan berbahasa, yaitu berbicara, mendengarkan, membaca, dan menulis.

Pada kurikulum K13 terdapat kompetensi dasar membaca dan menulis yang diajarkan secara terintegrasi dengan mata pelajaran yang lain. Oleh karena itu, dibutuhkan bahan ajar yang mampu mengintegrasikan kompetensi dasar agar dapat mengefisienkan dan mengoptimalkan kegiatan belajar mengajar. Integrasi yang dilakukan pada kompetensi dasar tersebut akan membuat siswa memperoleh pengetahuan dan keterampilan secara utuh meskipun terintegrasi dengan mata pelajaran yang lain, sehingga pembelajaran akan membuat lebih bermakna. Bermakna disini memberikan arti bahwa kegiatan pembelajaran membuat siswa memahami konsep-konsep pada kegiatan pembelajaran yang mereka pelajari melalui pengalaman langsung dan nyata yang menghubungkan antar konsep yang dipelajari dengan sebenarnya.

Keterampilan membaca dan menulis harus dimiliki peserta didik khususnya di kelas tiga, hal itu dikarenakan dengan memiliki keterampilan membaca dan menulis dapat mempermudah peserta didik pada kelas selanjutnya, observasi awal dilakukan oleh peneliti di SDN Tulusrejo 2 Kota Malang. Studi pendahuluan dilakukan peneliti guna mengetahui kegiatan membaca dan menulis, hasil belajar siswa, serta permasalahan dalam pembelajaran bahasa Indonesia, khususnya pada kemampuan membaca dan menulis.

Berdasarkan hasil obervasi yang dilakukan di lokasi SD diketahui keterampilan membaca dan menulis siswa kelas III adalah sebagai berikut: 1(a) guru membuka pembelajaran melakukan apersepsi, (b) pengelolaan pembelajaran dilakukan secara klasikal dan berkemlompok. 2) Kegiatan Inti: (a) guru meminta siswa untuk membaca kembali teks pendek peserta didik diminta melanjutkan; (b) guru melakukan tanya jawab dengan siswa; (c) siswa diminta untuk membaca dan rata-rata peserta didik dapat membaca dengan baik, akan tetapi untuk memahami dan menulis kembali apa yang sudah di tuliskan sedikit sulit. Peneliti juga melakukan wawancara yang dilakukan peneliti dengan guru kelas. Guru kelas III mengatakan kegiatan membaca dan menulis di kelas III tersebut kurang produktif. Siswa sudah bisa membaca dengan lancar akan tetapi masih belum bisa memahami apa yang telah di bacanya kemudian ditulis kembali. Guru sangat memerlukan cara yang tepat untuk mengatasi permasalahan belajar dan sikap siswa yang sulit diajak untuk membaca maupun menulis. Siswa lebih suka membaca komik dari pada buku pelajaran. Mereka lebih suka membaca komik daripada buku pelajaran dikarenakan tingkatan usia yang lebih menyukai membaca gambar daripada membaca teks, siswa lebih suka sesuatu yang penuh warna dan gambar daripada hanya berupa teks saja.

Dengan permasalahan yang dipaparkan di atas maka peneliti akan mengembangkan Bahan ajar cetak dalam bentuk komik hal ini dilakukan karena sesuai dengan pendapat Sujana dan Rivai (2010:68) mangemukakan "peran pokok dari buku komik dalam pengajaran adalah kemampuannya dalam menciptakan minat para siswa, sehingga komik akan dapat menjadi alat pengajaran yang efektif".

\section{METODE}

Model penelitian pengembangan merupakan dasar untuk mengembangkan produk yang akan dihasilkan. Produk yang dihasilkan pada penelitian ini adalah bahan jar cetak dalam bentuk komik menggunakan model Dick, Carey and 
Carey. Adapun langkah-langkahnya adalah sebagai berikut:

\section{Mengidentifikasi}

Tujuan Pembelajaran

Langkah awal pada tahap ini adalah menentukan tujuan pembelajaran yang akan diajarkan kepada peserta didik. Tujuan dari tahap ini adalah mengidentifikasi adanya kesenjangan antara tujuan menurut kondisi ideal yang seharusnya terjadi dengan fakta yang terjadi di lapangan.

2. Melakukan Analisis Pembelajaran (Conduct Instructional Analysis)

Setelah mengidentifikasi tujuan pembelajaran yang akan dilaksanakan, langkah selanjutnya adalah melakukan analisis pembelajaran. Analisis pembelajaran merupakan suatu prosedur yang digunakan untuk menentukan ketrampilan dan pengetahuan yang diperlukan oleh siswa untuk mencapai pengetahuan, ketrampilan dan sikap yang perlu dimiliki siswa setelah mengikuti pembelajaran.

3. Menganalisis keadaan belajar atau Konteks/Keadaan (Analyze Learner and Contexts).

Proses menganalisis pembelajar merupakan pemahaman terhadap siswa tentang keadaan belajar peserta didik yang meliputi keterampilan khusus, pengetahuan awal sebelum adanya pengembngan, gaya belajar. Identifikasi karakteristik siswa dapat membantu guru dalam memilih dan menentukan strategi pembelajaran yang akan digunakan.

\section{Merumuskan Tujuan Khusus \\ Pembelajaran (Write Performance Objective)}

Setelah menganalisis pembelajaran dan mengetahui karakteristik tingkah laku awal siswa, kemudian dirumuskan pernyataan khusus Tujuan pembelajaran khusus merupakan suatu rumusan mengenai kemampuan atau perilaku yang diharapkan dapat diperoleh oleh para siswa sesudah mengikuti pembelajaran melalui pengembangan bahan ajar cetak.
5. Mengembangkan

Instrumen

Penilaian (Develop Assessment Instrument)

Berdasarkan tujuan pembelajaran kemudian menyusun kompetensi yang telah dirumuskan, selanjutnya adalah mengembangkan instrumen penilaian untuk mengukur pencapaian hasil belajar dengan menggunakan bahan ajar cetak.
6. Mengembangkan Strategi Pembelajaran (Develop Instructional Stategy)
Langkah selanjutnya yaitu mengembangkan strategi pembelajaran pada langkah ini mengikuti hasil dari analisis keadaan pembelajar peserta didik. Siswa dapat belajar dengan mudah sesuai dengan karakteristiknya dalam menguasai bahan pembelajaran yang telah ditetapkan.

7. Mengembangkan dan Memilih Bahan Ajar (Develop and Selecting Instruction)

Berdasarkan analisis kebutuhan yang telah dilakukan maka pengembangan bahan ajar yang akan dikembangkan adalah bahan ajar cetak dalam bentuk komik. Draf yang disusun disesuaikan dengan kebutuhan serta kondisi yang ada pada sekolah yang dijadikan alasan peneliti melakukan pengembngan.

8. Merancang dan Mengembangkan Evaluasi Formatif (Design and Conduct Formative Evaluation)

Tujuan dari evaluasi formatif adalah untuk mengumpulkan data yang terkait dengan kekuatan dan kelemahan bahan ajar yang dikembangkan. Hasil dari proses evaluasi formatif dapat digunakan sebagai pertbaikan bahan yang dihasilkan. Evaluasi kelompok dibagi menjadi dua kelompok, yaitu evaluasi para ahli dan evaluasi penggunaan bagi siswa dan guru.

\section{Merevisi Bahan Pembelajaran (Revise Instrument) \\ Langkah akhir dari proses desain pengembangan adalah melakukan revisi terhadap draf bahan ajar. Revisi diperoleh}


dari evaluasi formatif yang telah dilakukan. Data yang diperoleh dari evaluasi formatif dikumpulkan dan diintepretasikan untuk mengetahui kelemahan-kelemahan bahan ajar cetak berbentuk komik keterampilan membaca dan menulis teks percakapan berbentuk komik.

\section{HASIL DAN PEMBAHASAN}

Pengembangan pada penelitian ini yaitu bahan ajar cetak dalam bentuk komik bahan ajar ini dapat digunakan secara klasikal di dalam kelas. Bahan ajar ini berisi tentang tentang keterampilan membaca dan menulis. Pengembangan bahan ajar teks berbentuk komik ditujukkan pada kemampuan siswa memahami dan menggunakan bahasa sebagai suatu alat komunikasi. Pada penelitian pengembangan ini membahas mengenai kemampuan siswa pada keterampilan membaca dan menulis. Iskandarwasyid dan Sunendar (2009:241) menyatakan bahwa membaca merupakan kegiatan untuk mendapatkan makna dari apa yang tertulis dalam teks. Kegiatan membaca mendominasi rangkaian kegiatan dalam bahan ajar cetak berbentuk komik. Hal itu terlihat dari uraian materi dan juga bacaan komik yang disajikan dalam latihan maupun tugas, yang selain bertujuan memberikan content materi juga bertujuan untuk meningkatkan keterampilan membaca siswa, serta penanaman sikap baik berdasarkan cerita komik yang dibaca. Tarigan (1986:22) mengemukakan "menulis ialah menuangkan atau menuliskan lambang-lambang grafik suatu bahasa dapat dipahami oleh seseorang, sehingga orang lain dapat

Penyajian data pada penelitian dan pengembangan bahan ajar cetak berbentuk komik dibedakan menjadi 5 jenis, yaitu (1) data validasi produk, (2) data kepraktisan produk, (3) data kemenarikan produk, (4) paparan data uji coba lapangan, dan (5) data keefektifan produk. Kelimanya dijelaskan berikut ini.

\section{Data Validasi Produk}

Data validasi produk menggunakan lembar validasi berupa angket. Data tersebut dikumpulkan untuk mengetahui tingkat kevalidan/ kelayakan bahan ajar cetak berbentuk komik sebelum di uji cobakan ke lapangan. Produk yang Validitas yang dilakukan peneliti meliputi: (1) validitas isi/ materi, (2) validitas bahasa, (3) validitas desain. Adapun penjelasan data validasi produk adalah sebagai berikut.

\section{a) Data Validasi Isi/ Materi}

Validasi ahli isi/materi diperlukan sebagai suatu bentuk evaluasi terhadap isi/materi serta penyajian produk yang telah dikembangkan. Data yang diperoleh berupa data kuantitatif dan kualitatif melalui angket yang diberikan peneliti kepada ahli isi/materi. Peneliti memberikan angket validasi isi/ materi dan produk yang dikembangkan. Berdasarkan perhitungan data angket yang diperoleh dari validasi ahli materi menunjukkan perolehan sebesar $96 \%$. Sesuai dengan perhitungan tersebut, maka dapat dinyatakan bahwa tingkat kevalidan bahan ajar cetak berbentuk komik dari aspek isi/materi mendapat kriteria sangat valid.

\section{b) Data Validasi Bahasa}

Validasi bahasa diperlukan sebagai evaluasi terhadap bahasa yang digunakan dalam produk yang sudah dikembangkan. Penggunaan bahasa yang efektif dan komunikatif sangatlah penting dalam sebuah bahan ajar cetak berbentuk komik. Dengan demikian, aspek ini pun sangat perlu divalidasi. Data yang diperoleh berupa data kuantitatif dan kualitatif melalui angket yang diberikan peneliti kepada ahli bahasa. Berdasarkan perhitungan data angket yang diperoleh dari validasi ahli bahasa menunjukkan perolehan sebesar 92\%. Dapat dinyatakan bahwa tingkat kevalidan dari bahan ajar cetak, untuk bahasa mendapat kriteria sangat valid. 


\section{c) Data Validasi Desain}

Validasi desain diperlukan sebagai evaluasi terhadap tampilan bahan ajar cetak. Data yang diperoleh berupa data kuantitatif dan kualitatif melalui angket yang diberikan peneliti kepada ahli desain pembelajaran Berdasarkan perhitungan data angket yang diperoleh dari validasi ahli desain menunjukkan perolehan sebesar $86 \%$. Sesuai dengan perhitungan tersebut, maka dapat dinyatakan bahwa tingkat kevalidan sangat valid. Secara kuantitatif, data validasi. Hasil efektifan dapat diuraikan dengan hasil belajar peserta didik

\section{d) Hasil Belajar Siswa}

Data hasil belajar adalah data yang berasal dari hasil pengerjaan latiha. Hasil belajar siswa pada aspek pengetahuan dapat dilihat pada tabel dapat diketahui bahwa hasil belajar siswa kelas III dengan penjabarannya sebanyak 2 siswa berada pada rentang 68-72, sebanyak 4 siswa berada pada rentang 73-77, sebanyak 8 siswa berada pada rentang 78-81, sebanyak 6 siswa berada pada rentang 82-86, sebanyak 4 siswa berada pada rentang 87-91, dan sebanyak 4 siswa berada pada rentang 92-96.

Berdasarkan tujuan dari pengembangan bahan ajar ini, yaitu untuk dapat memenuhi kebutuhan pada peserta didik di SDN tulusrejo 2 yang valid dan memiliki tingkat kemenarikan, keefektifan serta kepraktisan. Selanjutnya, produk ini akan dikaji berdasarkan: (1) wujud bahan ajar, (2) Kevalidan produk, (3) kemenarikan produk, (4) kepraktisan produk, dan (5) efektivitas bahan ajar.

\section{Wujud Produk}

Wujud bahan ajar ini berupa bahan ajar cetak yang didalamnya dikemas seperti komik serta ada buku guru sebagai pegangan yang digunakan sebagai panduan membelajarakan bahan ajar ini dapat dipelajari secara mandiri dan dipelajari secara klasikal dengan panduan. Adapun aspek-aspek dalam bahan ajar akan dijelaskan sebagaimana berikut ini.

\section{a. Keterampilan Menulis}

Pembelajaran bahasa Indonesia di SD difokuskan pada kemampuan siswa untuk dapat menulis dengan baik. Pada penelitian pengembangan ini membahas mengenai kemampuan siswa pada keterampilan menulis. Keterampilan menulis merupakan salah satu bentuk keterampilan produktif berarti keterampilan menyampaikan gagasan dalam bentuk ujaran dan tulisan. Keterampilan menulis. Tarigan (1986:22) mengemukakan "menulis ialah menuangkan atau menuliskan lambanglambang grafik suatu bahasa dapat dipahami oleh seseorang, sehingga orang lain dapat membaca lambang-lambang grafik tersebut kalau mereka memahami bahasa"

\section{b. Aspek Isi Produk}

Isi produk pengembangan bahan ajar cetak berbentuk komik ini kompetensi dasar yang diambil yaitu Menulis dialog sederhana antara dua atau tiga tokoh dengan memperhatikan isi serta perannya. Untuk dapat mencapai indikator-indikator yang telah diuraikan di atas, bahan ajar dilengkapi dengan konsep, prosedur, ilustrasi, dan juga contoh. Selain hal-hal pokok di atas, bahan ajar ini juga berisi kolom khusus lainnya. Kolom khusus tersebut yaitu Bermain-main. Bermain-main permainan yang disajikan secara menarik untuk membuat siswa merasa senang menggunakan bahan ajar ini.

\section{c. Aspek Bahasa}

Bahan ajar ini menggunakan bahasa yang komunikatif, hal ini didasarkan karena tingkatan usia pengguna bahan ajar ini. Muslich (2010:303) menyatakan bahwa salah satu indikator kelayakan bahasa adalah pemakaian bahasa yang komunikatif. Artinya, bahasa dalam bahan ajar mengutamakan komunikasi antara penulis dan pembaca. Komunikatif dikatakan bahwa kalimat yang digunakan padat, singkat dan mudah dipahami 
siswa. Selanjutnya, kalimat-kalimat disusun menjadi paragraf yang utuh yang memiliki makna pada masing-masing penggalan dan pembelajaran. Bahan ajar ini ditunjukkan kepada siswa Sekolah Dasar, maka bahasa yang digunakan disesuaikan dengan tingkat perkembangan siswa.

\section{d. Aspek Penyajian}

Sebuah bahan ajar yang dikebangkan harus memperhatikan penyajiannya. Sitematika peyajian tersebut tidak semuanya dimasukkan. Bagian pendahulu mencakup: (1) kata pengantar, (2) petunjuk penggunaan (3) uraian materi, (4) ayo menulis (5) mengarang indah, (6) tugas, (7) kesimpulan, (8) kerja sama dengan orang tua, ((9)) tes akhir (10) bersenang-senang. Sementara itu, pada bagian penutup memuat: (1) daftar rujukan, (2) kamus mini, (3) pedoman penilaian.

Bahan ajar cetak berbentuk komik ini juga dilengkapi Pedoman guru yangberisi petunjuk penggunaan yang meliputi. Pada bagian pendahuluan berisi: (1) kata pengantar, (2) tentang pedoman guru, (3) penggunaan pedoman guru, dan (5) daftar isi. Bagian isi pedoman untuk guru berisi: (1) identitas mata pelajaran, (2)tujuan pedoman guru, (3)isi komik, (6) KI dan KD, (7) indikator, (8) tujuan pembelajaran, (9) alokasi waktu, (10) peranan guru dalam proses pembelajaran.

\section{e. Aspek Penampilan Bahan ajar cetak berbentuk komik}

Aspek penampilan meliputi: 1) jenis dan ukuran huruf, (2) tata letak dan sistem penomoran, (3) penggunaan ilustrasi Bahan ajar cetak berbentuk komik ini menggunakan dua jenis huruf. Tidak menggunakan huruf hias, tidak menggunakan variasi huruf yang berlebihan. Variasi terletak pada ukuran dan warna. Jenis huruf yang digunakan adalah Times New Roman (pada tiap judul bagian pendahuluan, judul penggalan, judul kegiatan belajar, judul pada bagian penutup) dan Comic Sans $M S$ (pada bagian uraian teksnya). Ukuran huruf yang digunakan yaitu 9pt, 11pt, 12pt, 22pt, 24pt.

Ilustrasi yang disajikan memiliki bertujuan untuk memperjelas pemahaman yang dimulai dari segi tampilan warnya yang mana dipi;ih warna-warna cerah yang sesuai dengan pedoman warna untuk siswa tingkatan sekolah dasar. Gambar-gambar yang disajikan merupakan gambar yang sesuai dengan tingkatan usia peserta didik. Komik dipilih berdasarkan isi cerita yang terdapat dalam komik, menceritakan kehidupan sehari-hari siswa, sesuai dengan tingkatan usia peserta yaitu peneliti memilih komik berwarna untuk menarik minat siswa untuk membacanya. Warna merupakan komunikasi nonverbal yang memiliki makna. Menurut Arsyad (2010:110) warna merupakan unsur visual yang penting, tetapi harus digunakan dengan hati-hati untuk memperoleh dampak yang baik. Warna yang ditampilkan pada setiap penggalan konsisten. Untuk bagian penutup, warna dan tata letak dan variasinya dibentuk seperti bagian pendahuluan, dengan perbedaan warna tiap judul bagiannya. Untuk warna teks harus kontras dengan warna latar agar pesan yang disampaikan mudah dipahami oleh pembaca.

\section{KESIMPULAN DAN SARAN \\ Kesimpulan}

Dapat disimpulkan Produk yang dihasilkan dalam pengembangan ini adalah bahan ajar cetak yang diperuntukkan untuk siswa kelas III tingkatan Sekolah Dasar. Pengembangan ini dilakukan dengan adanya permasalahan yang muncul. Studi pendahuluan dilakukan untuk mengetahui kemampuan berbahasa siswa, khususnya menulis, proses pembelajaran, maupun bahan ajar yang selama ini digunakan untuk belajar.

Kevalidan sebuah produk sangatlah penting untuk mengetahui kelayakan dari produk yang dikembangkan sebelum digunakan dalam uji coba lapangan. 
Selain mengetaui kelayakan, peneliti juga akan mengetahui kelemahan dan kelebihan dari produk yang dikembangkan. Aspek kevalidan produk mendapat respon positif dari validator. Hal ini dapat dilihat produk yang dikembangkan, untuk bahan ajar cetak berbentuk komik siswa didapat hasil validasi total dilihat dari isi dan penyajian, bahasa, dan desain mendapat skor persentase rata-rata sebesar 91,67\% sangat valid. Sedangkan, untuk pedoman guru validasi total mendapat skor persentase rata-rata sebesar $91 \%$ dengan kriteria sangat valid.

Kepraktisan produk sangatlah penting walaupun sifatnya subjektif. Dikatakan demikian karena produk yang praktis akan mudah dipelajari, efektif dan efisien dalam penggunaannya. Kepraktisan menentukan kemudahan dari mempelajarinya, tersampaikannya isi bahan ajar kepada segmentasi sasaran. Aspek kepraktisan produk mendapat respon positif dari guru. Hal ini dapat dilihat produk yang dikembangkan (bahan ajar cetak berbentuk komik siswa dan pedoman guru) sama-sama mendapat skor persentase rata-rata sebesar $99 \%$.

Kemenarikan bahan ajar cetak berbentuk komik sangatlah penting walaupun sifatnya subjektif. Dikatakan demikian karena bahan ajar cetak berbentuk komik yang menarik dapat menjadi rangsangan bagi siswa untuk membaca dan mempelajari bahan ajar cetak berbentuk komik. Kemenarikan menentukan tersampaikannya isi bahan ajar cetak berbentuk komik kepada pembaca (siswa). Aspek kemenarikan bahan ajar cetak berbentuk komik mendapat respon positif dari siswa. Hal ini dapat dilihat hasil kemenarikan bahan ajar cetak berbentuk komik dari siswa mendapat skor persentase rata-rata sebesar $94 \%$ dengan kriteria sangat menarik.

Efektifitas artinya suatu ukuran yang menyatakan pemahaman pengguna dari target telah tercapai. Semakin besar persentase target yang dicapai, semakin tinggi pula efektivitasnya. Efektifitas bahan ajar cetak berbentuk komik dilihat dari hasil belajar siswa, pengamatan proses, dan hasil wawancara dengan guru dan siswa. Dilihat dari segi kefektifannya, bahan ajar cetak berbentuk komik yang dikembangkan efektf digunakan dalam pembelajaran.

Produk ini memiliki kelebihan dan kekurangan. Kelebihan yaitu: 1) didesain sesuai dengan karakteristik siswa, 2) bahan ajar cetak berbentuk komik ini berorientasi pada tujuan pembelajaran ,3) isi bahan ajar cetak berbentuk komik lebih menfokuskan kepada keterampilan menulis ,4)bahan ajar cetak berbentuk komik dikembangkan dengan memperhatikan pengetahuan, sikap dan keterampilan siswa.

\section{Saran}

Bahan ajar yang dikembangkan dapat dimanfaatkan oleh siswa sebagai bahan belajar. Siswa dianjurkan untuk belajar secara mandiri. Siswa juga dianjurkan untuk belajar dengan tertib. Artinya, siswa diminta mengisi kembali kata-kata rumpang pada bahan ajar cetak berbentuk komik.

\section{DAFTAR PUSTAKA}

Arsyad, Azhar. 2010. Media

Pembelajaran. Jakarta: PT Raya

Grafindo Persada.

Dick, W., Carey, L., \& Carey, J. O. 2009.

The Systematic Design of

Instruction (Seventh Edition).

New Jersey: Pearson Education Inc

Hobri. 2010. Metodologi Penelitian

Pengembangan (Aplikasi Pada

Penelitian Pendidikan

Matematika). Jember: Pena

Salsabila.

Iskandarwasid dan Sunendar, Dadang. 2008. Strategi Pembelajaran

Bahasa. Bandung: PT Remaja

Rosdakarya. 
Muslich, M. 2009. Melaksanakan PTK

Itu Mudah. Jakarta: Bumi Aksara

Muslich, M. 2010. Text Book Writing.

Yogyakarta: Ar-Ruzz Media.

Sudjana dan Rivai. 2010. Media pengajaran. Bandung: Sinar Baru Algensindo.

Tarigan, H. G. 1990. Membaca Sebagai Suatu Keterampilan Berbahasa. Bandung: Angkasa.

Tarigan, H. G. 1986. Menulis sebagai Suatu Keterampilan Berbahasa. Bandung: Penerbit Angkasa.

Tarigan, D., \& Tarigan, H. G. 1987.

Teknik Pengajaran Keterampilan Berbahasa. Bandung: Angkasa.

Wahyuni, S., \& Ibrahim, A. S. 2012. Asesmen Pembelajaran Bahasa. Bandung: Refika Aditama. 